\title{
PENGGUNAAN METODE FROZEN INITIAL LIABILITY PADA \\ PERHITUNGAN PENDANAAN PENSIUN MANFAAT PASTI \\ (Studi Kasus: Data Pegawai Negeri Sipil di Puskesmas Kecamatan Hulu Gurung Kabupaten Kapuas Hulu)
}

\author{
Zul Alfikri, Neva Satyahadewi, Hendra Perdana
}

\begin{abstract}
INTISARI
PNS memiliki peran penting dalam pembangunan nasional sehingga perlu diberikan perlindungan serta peningkatan kesejahteraan PNS untuk dapat meningkatkan produktivitas kerjanya. Usaha peningkatan kesejahteraan PNS dan keluarganya dilakukan melalui penyelenggaraan program pensiun. Penelitian ini membahas program pensiun manfaat pasti, yang manfaat pensiunnya ditentukan di awal berdasarkan peraturan dana pensiun. Setelah diketahui besar manfaat pensiun yang akan diberikan kepada pegawai, harus dianalisis nilai iuran normal dan kewajiban aktuaria. Keduanya dapat dianalisis dengan menggunakan metode perhitungan aktuaria, yaitu metode Frozen Initial Liability (FIL). Data yang digunakan dalam penelitian ini adalah data PNS yang bekerja di Puskesmas Kecamatan Hulu Gurung, Kabupaten Kapuas Hulu. Penelitian ini bertujuan untuk menganalisis nilai iuran normal dan kewajiban aktuaria pada PNS menggunakan metode FIL. Hasil analisis perhitungan menunjukkan bahwa pada kurun waktu 0-20 tahun, iuran normal yang harus dibayarkan oleh setiap anggota kelompok program pensiun yang memiliki 31 anggota dengan nilai suku bunga tahunan 6\% adalah sebesar Rp 275.832,00 setiap bulan. Nilai kewajiban aktuaria yang harus dicadangkan oleh perusahaan dana pensiun untuk semua anggota pada kurun waktu 0 tahun yaitu sebesar Rp 21.454.598,00. Secara keseluruhan kurun waktu, didapatkan bahwa nilai iuran normal yang dihitung dengan menggunakan metode FIL untuk setiap waktu ialah bersifat konstan namun iuran normal akan mengalami penurunan apabila terdapat anggota kelompok yang memasuki usia pensiun normal ( $y=56$ tahun). Nilai kewajiban aktuaria akan terus meningkat setiap tahunnya meskipun terdapat anggota yang keluar dari kelompok program pensiun, namun pada saat tertentu terdapat penurunan nilai kewajiban aktuaria.
\end{abstract}

Kata kunci: PNS, pensiun, manfaat pasti, iuran normal, kewajiban aktuaria, FIL

\section{PENDAHULUAN}

Indonesia merupakan salah satu negara berkembang yang ada di dunia. Oleh karena itu, Indonesia pun terus berusaha untuk menjadi salah satu negara maju di dunia dan mengejar ketertinggalan dengan berbagai strategi untuk mencapai tujuan tersebut. Salah satu strateginya adalah dengan melakukan pembangunan nasional. Dalam hal ini, Pegawai Negeri Sipil (PNS) merupakan profesi yang mempunyai kedudukan dan peranan penting serta menentukan dalam pembangunan nasional. Oleh karena pentingnya peran PNS dalam pembangunan nasional maka perlu diberikan perlindungan, pemeliharaan serta peningkatan kesejahteraan PNS sehingga dapat meningkatkan produktivitas kerja. Usaha peningkatan kesejahteraan PNS dan keluarganya dilakukan melalui penyelenggaraan program pensiun. Program pensiun merupakan suatu program yang mengupayakan manfaat pensiun bagi pesertanya melalui suatu sistem pemupukan yang lazim disebut sistem pendanaan.

Pada sistem dana pensiun terdapat beberapa manfaat pensiun yang diberikan sebagai manfaat tambahan karena kematian, pensiun dipercepat (keluar), pensiun karena tidak bisa bekerja (cacat), dan pensiun pada saat usia pensiun [1]. Manfaat pensiun yang dibayarkan bagi peserta yang telah mencapai masa pensiun sering juga disebut dengan manfaat pensiun normal [2]. Pada penelitian ini, nilai manfaat pensiun telah ditetapkan dengan rumus atau formula tertentu di awal kesepakatan sesuai 
dengan gaji pegawai, sedangkan nilai iuran normal dan kewajiban aktuaria belum diketahui. Nilai manfaat yang diterima tentunya ada yang sama dan berbeda tergantung dari usia masuk dan masa kerja yang akan mempengaruhi besar kecilnya iuran yang harus dibayar oleh setiap pegawai. Pada dasarnya, jika manfaat pensiun yang diterima masing-masing pegawai adalah berbeda maka nilai iuran normal yang akan dibayarkan juga akan berbeda. Permasalahannya adalah besarnya iuran yang akan dibayar oleh setiap pegawai adalah sama meskipun manfaat yang diperoleh setiap pegawai adalah berbedabeda pada masa pensiunnya. Salah satu metode perhitungan aktuaria untuk menganalisis permasalahan tersebut yaitu dengan menggunakan metode Frozen Initial Liability (FIL).

Metode FIL merupakan adaptasi dari metode Entry Age Normal (EAN). Metode EAN adalah metode pendanaan yang perhitungannya berdasarkan usia peserta saat pertama kali masuk kerja sampai usia pensiun. Metode FIL digunakan untuk menghitung besarnya pendanaan pensiun pada suatu grup atau kelompok tertentu dengan mengasumsikan bahwa besarnya iuran yang akan dibayarkan oleh setiap anggota kelompok adalah sama meskipun setiap anggota kelompok mendapatkan nilai manfaat yang berbeda-beda pada masa pensiunnya [3]. Oleh karena itu, penelitian ini bertujuan untuk menganalisis nilai iuran normal dan kewajiban aktuaria pada PNS yang bekerja di Pusat Kesehatan Masyarakat (Puskesmas) Kecamatan Hulu Gurung, Kabupaten Kapuas Hulu menggunakan metode FIL dengan bantuan Tabel Mortalita Indonesia tahun 2011 (1). Menganalisis hasil iuran normal dan kewajiban aktuaria jika terdapat anggota kelompok yang keluar dari suatu kelompok pada waktu tertentu dikarenakan telah mencapai usia pensiun normal (2).

Batasan masalah pada perhitungan pendanaan pensiun manfaat pasti ini antara lain gaji awal bekerja menyesuaikan golongan awal dan daftar gaji pokok PNS, penentuan total gaji setiap PNS pada tahun berikutnya tidak menyesuaikan golongan dan masa kerja golongan tetapi ditentukan oleh total gaji pada tahun sebelumnya, masa kerja, dan persentase tingkat kenaikan gaji. Langkah pertama dalam penelitian ini adalah menentukan jumlah PNS yang bekerja di Puskesmas, usia saat pertama kali pegawai tersebut masuk kerja di Puskesmas, usia pensiun, golongan awal, gaji awal bekerja masingmasing PNS, Tabel Mortalita Indonesia (TMI) tahun 2011 dan Tabel Service. Selanjutnya mengasumsikan bahwa tingkat kenaikan gaji $(I)$ sebesar $5 \%$, proporsi dari gaji yang dipersiapkan untuk manfaat pensiun $(k)$ sebesar 2,5\% dari gaji selama bekerja dan tingkat suku bunga $(i)$ pada bulan Januari 2019 sebesar 6\% dengan $i$ tidak berubah untuk setiap tahunnya. Setelah menganalisis data update PNS dan gaji awal bekerja beserta asumsi-asumsinya, maka dapat ditentukan fungsi gaji atau total gaji setiap tahunnya, fungsi manfaat pensiun, komponen-komponen tambahan pada TMI tahun 2011 dan Tabel Service. Langkah selanjutnya, maka dapat dihitung kumulatif total gaji, kumulatif fungsi manfaat pensiun, selisih manfaat pensiun, fungsi anuitas hidup yang pembayarannya dilakukan diawal masing-masing periode sebanyak $m$ kali dalam setahun, dan nilai sekarang manfaat pensiun untuk masing-masing pegawai atau peserta. Langkah terakhir adalah menghitung nilai iuran normal dan kewajiban aktuaria menggunakan metode FIL. Proses perhitungannya menggunakan bantuan software Microsoft Excel.

\section{TABEL MORTALITA}

Tabel mortalita berisi peluang seseorang meninggal menurut usia dari kelompok orang yang diasuransikan (pemegang polis asuransi). Simbol $l_{x}$ digunakan untuk menyatakan banyaknya orang yang tepat berusia $x$, simbol $d_{x}$ menyatakan banyaknya orang yang meninggal antara usia $x$ hingga $x+$ 1 , dan simbol ${ }_{n} d_{x}$ menyatakan banyaknya orang yang meninggal antara usia $x$ hingga $x+n$,

$$
d_{x}=l_{x}-l_{x+1}
$$

Pada tabel mortalita terlihat adanya fungsi antara usia dengan waktu. Perhitungan yang menggunakan hubungan antara usia dan waktu digunakan untuk menentukan peluang hidup atau mati [1]. Peluang orang berusia $x$ akan mencapai usia $x+1$ dinyatakan dalam simbol $p_{x}$.

$$
\frac{l x+1}{l x}
$$


Peluang orang berusia $x$ akan hidup paling sedikit $n$ tahun dinyatakan dalam simbol ${ }_{n} p_{x}$ [4].

$$
{ }_{n} p_{x}=\frac{l_{x+n}}{l_{x}}
$$

peluang orang berusia $x$ akan meninggal sebelum usia $x+1$ dinotasikan dengan $q_{x}$ [4].

$$
q_{x}=1-p_{x}=1-\frac{l_{x+1}}{l_{x}}=\frac{l_{x}-l_{x+1}}{l_{x}}=\frac{d_{x}}{l_{x}}
$$

Simbol komutasi yang menyatakan hasil perkalian dari fungsi bunga $\left(v^{x}\right)$ dengan jumlah orang yang tepat berusia $x$ tahun $\left(l_{x}\right)$ dinotasikan dengan $D_{x}[1]$.

$$
D_{x}=l_{x} \cdot v^{x}
$$

Simbol komutasi yang menyatakan jumlah dari $D_{x}$ dinotasikan dengan $N_{x}[1]$.

$$
N_{x}=\sum_{x}^{111} D_{x}
$$

\section{FUNGSI DASAR AKTUARIA}

Fungsi dasar aktuaria terdiri dari seluruh fungsi yang akan mempresentasikan asumsi aktuaria dan beberapa fungsi yang digunakan untuk menghitung anuitas, manfaat pensiun, iuran normal, dan kewajiban aktuaria dana pensiun. Berikut dibahas lebih lanjut mengenai fungsi dasar aktuaria yang digunakan dalam menghitung dana pensiun, antara lain [2]:

\section{Fungsi Survival Komposit}

Fungsi survival komposit adalah fungsi yang menggambarkan peluang seorang pegawai akan tetap bekerja selama masa kerja aktif, sampai waktu yang diperbolehkan untuk pensiun dengan memperhatikan semua tingkat penyebab yang dikenakan kepada setiap peserta program pensiun. Setiap peluang yang digunakan berdasarkan TMI 2011. Peluang seorang pegawai akan tetap bekerja selama masa aktif sepanjang $n$ tahun sama dengan perkalian peluang survival komposit selama $n$ tahun berturut-turut sehingga dapat dirumuskan sebagai berikut [2]:

$$
{ }_{n} p_{x}^{(T)}=\prod_{t=1}^{n}{ }_{t} p_{x}^{(T)}
$$

dengan:

$T=$ total atau kumulatif

${ }_{n} p_{x}^{(T)}=$ kumulatif peluang seorang pegawai yang berusia $x$ akan tetap bekerja untuk $n$ tahun mendatang

$x \quad=$ usia (dalam tahun)

$t \quad=$ periode atau waktu (dalam tahun)

$n \quad=$ lama bekerja

\section{Fungsi Bunga}

Fungsi bunga digunakan untuk mendiskontokan suatu pembayaran yang akan datang ke waktu yang sekarang. Jika $i_{t}$ adalah tingkat suku bunga yang diasumsikan untuk tahun ke $t$, maka [2]:

dan jika $i_{1}=i_{2}=\cdots=i_{n}$, maka diperoleh

$$
v^{n}=\frac{1}{\left(1+i_{1}\right)\left(1+i_{2}\right) \ldots\left(1+i_{n}\right)}
$$

$$
v^{n}=\frac{1}{(1+i)^{n}}
$$

Simbol $v^{n}$ adalah faktor diskonto (discount factor), yaitu nilai sekarang dari pembayaran sebesar 1 satuan yang jatuh tempo dalam $n$ tahun dengan tingkat bunga majemuk tahunan sama dengan $i$.

\section{Fungsi Gaji}


Apabila dalam program pensiun mempunyai manfaat (benefit) yang berkaitan dengan tingkat kenaikan gaji pegawai atau peserta program pensiun, maka diperlukan perumusan notasi gaji dan prosedur untuk mengestimasi atau menduga gaji dimasa mendatang. Rumus yang digunakan untuk fungsi gaji adalah:

dengan:

$$
S_{x}=\sum_{t=w}^{x-1} s_{t}
$$

$w \quad=$ usia peserta ketika masuk menjadi anggota pensiun

$S_{x} \quad=$ kumulatif gaji peserta dari usia $w$ sampai $x-1$ tahun

$s_{t} \quad=$ gaji peserta saat $t$ tahun bekerja

Dalam hal ini digunakan tingkat kenaikan gaji, misalkan suatu model tingkat kenaikan gaji per tahun sebesar $I$. Tingkat kenaikan gaji ini meningkat menjadi [1]:

$$
s_{x+t}=s_{x} \cdot(1+I)^{t}
$$

dengan:

$I \quad=$ tingkat kenaikan gaji

4. Fungsi Manfaat

Fungsi manfaat digunakan untuk menentukan besar manfaat pensiun yang akan diterima pegawai pada saat pensiun, pengunduran diri, cacat, dan meninggal dunia pada masa aktif. Rumus yang digunakan untuk menghitung besarnya manfaat yang akan diterima pegawai saat pensiun pada usia $x$ adalah:

dengan:

$$
B_{x}=\sum_{t=w}^{x-1} b_{t}
$$

$B_{x}=$ kumulatif manfaat pensiun yang diperoleh pegawai yang berusia $w$ sampai $x-1$ tahun

$b_{t}=$ besarnya manfaat pensiun pada tahun ke- $t$

Dalam penelitian ini, digunakan formula career average. Berdasarkan formula career average, nilai manfaat pensiun diperoleh dari hasil perkalian gaji dengan suatu konstanta yang merupakan persentase dari gaji yang diberikan untuk manfaat. Untuk $b_{x}$ dan $B_{x}$ didefinisikan sebagai:

dengan:

$$
\begin{aligned}
& b_{x}=k s_{x} \\
& B_{x}=k S_{x}
\end{aligned}
$$

$k=$ proporsi gaji rata-rata yang disediakan per tahun masa kerja

5. Fungsi Anuitas

Anuitas adalah serangkaian pembayaran yang dilakukan pada interval waktu yang sama. Adapun pembayarannya bisa dilakukan pada awal tahun $\left(\ddot{a}_{x}\right)$ atau akhir tahun $\left(a_{x}\right)$, tergantung lamanya pembayaran berlangsung, sehingga diperoleh hubungan sebagai berikut [5]:

$$
\ddot{a}_{x}=1+a_{x}
$$

Secara matematika, anuitas hidup dapat diartikan sebagai perpaduan dari fung $\left(\beta_{i} p(s t i) \eta v i v a l\right.$ dan fungsi bunga $\left(v^{t}\right)$ yang perumusannya dinyatakan sebagai berikut [2]:

$$
a_{x}=\sum_{t=1}^{\infty}{ }_{t} p_{x}^{(m)} v^{t}=\frac{N_{x+1}}{D_{x}}
$$

sehingga diperoleh:

$$
\ddot{a}_{x}=1+\sum_{t=1}^{\infty}{ }_{t} p_{x}^{(m)} v^{t}=\frac{N_{x}}{D_{x}}
$$

Apabila pembayaran dilakukan di awal masing-masing periode sebanyak $m$ kali dalam setahun dengan jumlah pembayaran sebesar 1, maka rumusnya adalah [2]: 


$$
\ddot{a}_{x}^{(m)}=\ddot{a}_{x}-\frac{m-1}{2 m}
$$

dengan:

$\ddot{a}_{x} \quad=$ anuitas awal seumur hidup

$a_{x} \quad=$ anuitas akhir seumur hidup

$m \quad=$ kematian (mortality)

${ }_{t} p_{x}^{(m)}=$ peluang orang berusia $x$ tahun akan hidup paling sedikit $t$ tahun

$N_{x} \quad=$ simbol komutasi yang menyatakan jumlah dari $D_{x}$ dengan $x$ tahun sampai dengan usia maksimal

$D_{x} \quad=$ simbol komutasi yang menyatakan hasil perkalian dari faktor diskonto $\left(v^{x}\right)$ dengan jumlah orang yang tepat berusia $x$ tahun $\left(l_{x}\right)$

\section{PRESENT VALUE OF FUTURE BENEFIT (PVFB)}

$P V F B$ adalah nilai sekarang dari manfaat pensiun berkala yang akan diterima oleh peserta program dana pensiun setiap tahun. Secara matematis, ${ }^{y}(P V F B)_{x}$ dirumuskan sebagai berikut [2]:

$$
{ }^{y}(P V F B)_{x}=B(y) v_{(y-x)}^{(y-x)} p_{x} \ddot{a}_{y}^{(12)}=B(y) \ddot{a}_{y}^{(12)} \frac{D_{y}}{D_{x}}
$$

dengan:

$$
\begin{array}{ll}
y & =\text { usia pensiun } \\
y(P V F B)_{x} & =\text { nilai sekarang dari manfaat pensiun pada usia } x \text { tahun } \\
B(y) & =\text { kumulatif manfaat pensiun pada usia pensiun normal }(y=56 \text { tahun }) \\
\ddot{a}_{y}^{(12)} & =\text { nilai pada umur } y \text { dari anuitas hidup yang dibayarkan setiap bulan sebesar } \frac{1}{12} \text { satuan }
\end{array}
$$

\section{PRESENT VALUE OF FUTURE NORMAL COST (PVFNC)}

$P V F N C$ adalah nilai sekarang dari iuran normal yang dibayarkan oleh peserta program pensiun. $P V F N C$ dari peserta pada waktu $t$ (dalam tahun) atau pada usia $x$ tahun dinotasikan dengan ${ }^{y}(P V F N C)_{x}$. Secara matematis, ${ }^{y}(P V F N C)_{x}$ dirumuskan sebagai berikut [2]:

dengan:

$$
{ }^{y}(P V F N C)_{x}=\sum_{t=x}^{y-1} y(N C)_{t(t-x)} p_{x} v^{(t-x)}={ }^{y}(N C)_{x} \frac{N_{x}-N_{y}}{D_{x}}
$$

${ }^{y}(\text { PVFNC })_{x}=$ nilai sekarang dari iuran normal pada usia $x$ tahun

${ }^{y}(N C)_{t} \quad=$ iuran normal yang dibayarkan oleh setiap peserta program pensiun pada waktu $t$

\section{METODE FROZEN INITIAL LIABILITY (FIL)}

Metode FIL merupakan salah satu metode pendanaan program pensiun yang merupakan adaptasi dari metode entry age normal. Metode ini digunakan untuk menghitung besarnya pendanaan pensiun pada suatu anggota atau kelompok tertentu dengan mengasumsikan bahwa besarnya iuran yang akan dibayarkan oleh setiap anggota kelompok adalah sama meskipun setiap anggota kelompok mendapatkan nilai manfaat yang berbeda-beda pada masa pensiunnya. Pada metode ini, jika terdapat anggota kelompok yang keluar dari sistem pendanaan pensiun disebabkan oleh peserta tersebut telah mencapai usia pensiun normal ( $y=56$ tahun) maka anggota tersebut berhenti membayar iuran normal. Perhitungan menyisakan anggota peserta lain yang belum mencapai usia pensiun normal.

1. Iuran Normal (Normal Cost)

Iuran normal adalah iuran tahunan yang dibayarkan oleh peserta program dana pensiun kepada perusahaan sesuai peraturan dana pensiun. Metode $F I L$ ini mengasumsikan bahwa iuran normal $N C_{t}^{(j)}$ setiap peserta atau pegawai $j$ adalah sama untuk semua peserta $j \in A_{t}$. Besarnya iuran normal untuk setiap anggota dalam suatu kelompok menggunakan metode FIL dirumuskan sebagai berikut [3]: 
Keterangan:

$$
N C_{t}^{(j)}=\frac{1}{n t} \sum_{j \in A t} B(y)_{j} \ddot{a}_{y}^{(12)} \frac{D_{y_{j}}}{N_{w_{j}}-N_{y_{j}}}
$$

$N C_{t}^{(j)}=$ iuran normal yang dibayarkan oleh pegawai $j$ pada waktu $t$ dengan $j$ adalah pegawai yang merupakan anggota peserta pensiun dari himpunan anggota $A_{t}$

$n_{t} \quad=$ jumlah pegawai yang mengikuti program pensiun pada waktu $t$

$A_{t} \quad=$ himpunan anggota peserta pensiun pada waktu $t$

$B(y)_{j} \quad=$ manfaat pensiun untuk pegawai $j$ yang pensiun pada usia $y$ tahun

Nilai ini $\frac{D_{y_{j}}}{N_{w_{j}}-N_{y_{j}}}$ berdasarkan tabel service [5].

2. Kewajiban Aktuaria (Actuarial Liability)

Kewajiban aktuaria adalah besarnya dana pensiun yang seharusnya telah terkumpul untuk pembayaran manfaat pensiun yang akan datang. Kewajiban aktuaria dapat dianalogikan dengan cadangan manfaat. Dengan menggunakan metode $F I L$, kewajiban aktuaria pada waktu $t+1$ dapat dirumuskan dengan [3]:

$$
\begin{aligned}
(A L)_{t+1}= & (A L)_{t}(1+i)-\left(\sum_{j \in T}(P V F B)_{t+1_{j}}-\sum_{j \in A_{t}} q_{x_{j}}(P V F B)_{t+1_{j}}\right)- \\
& \sum_{j \in R}(P V F B)_{t+1_{j}}+\sum_{j \in A_{t+1}} \Delta B(x)_{j} \ddot{a}_{y}^{(12)} \frac{D_{y_{j}}}{D_{x+1_{j}}}- \\
& (N C)_{t+1} \frac{1}{n_{t+1}} \sum_{j \in A_{t+1}} \frac{N_{x+1_{j}}-N_{y_{j}}}{D_{x+1_{j}}}+(1+i)(N C)_{t} \frac{1}{n_{t}} \sum_{j \in A_{t}} \frac{N_{x_{j}}-N_{y_{j}}}{D_{x_{j}}}
\end{aligned}
$$

Keterangan:

$$
\begin{aligned}
& (A L)_{t} \quad=\text { kewajiban aktuaria pada waktu } t \\
& i \quad=\text { tingkat suku bunga per tahun } \\
& j \in T \quad=\text { anggota kelompok } j \text { yang tidak menerima hak pensiunnya } \\
& q_{x_{j}} \quad=\text { peluang pegawai } j \text { berusia } x \text { tahun pada saat } t \text { akan meninggal pada usia } x+1 \\
& \text { tahun } \\
& \begin{aligned}
\sum_{j \in T}(P V F B)_{t+1_{j}} \quad= & \text { jumlah dari nilai sekarang manfaat pensiun pada waktu } t+1 \text { untuk anggota } \\
& \text { kelompok } j \text { yang tidak menerima hak pensiunnya }
\end{aligned} \\
& j \in R \quad=\text { anggota kelompok } j \text { yang menerima hak pensiunnya } \\
& \sum_{j \in R}(P V F B)_{t+1_{j}} \quad \begin{array}{l}
\text { jumlah dari nilai sekarang manfaat pensiun pada saat } t+1 \text { untuk anggota } \\
\text { kelompok } j \text { yang menerima hak pensiunnya }
\end{array} \\
& \Delta B(x)_{j} \quad=\text { selisih manfaat pensiun untuk pegawai } j \text { yang berusia } x \text { dan } x+1 \text { tahun }
\end{aligned}
$$

Nilai $D_{y_{j}}, D_{x_{j}}, D_{x+1_{j}}, N_{y_{j}}, N_{x_{j}}$, dan $N_{x+1_{j}}$ berdasarkan tabel service [6].

\section{STUDI KASUS}

Data yang digunakan dalam penelitian ini berupa data sekunder Pegawai Negeri Sipil (PNS) yang bekerja di Pusat Kesehatan Masyarakat (Puskesmas) Kecamatan Hulu Gurung yang berjumlah 31 orang. Adapun variabel-variabel yang diperlukan untuk perhitungan dana pensiun dalam penelitian ini antara lain jenis kelamin, usia pertama kali masuk kerja, golongan awal bekerja, dan gaji awal bekerja. Data PNS ini diambil dari Puskesmas Kecamatan Hulu Gurung Kabupaten Kapuas Hulu.

Asumsi dan ketentuan yang digunakan dalam program pensiun manfaat pasti dengan menggunakan metode $F I L$, antara lain:

1. Usia pensiun normal (y) ditetapkan 56 tahun.

2. Tingkat kenaikan gaji ( $I$ ) sebesar $5 \%$ diasumsikan sama untuk setiap tahunnya.

3. Tabel mortalita yang digunakan adalah Tabel Mortalita Indonesia tahun 2011 untuk laki-laki dan perempuan dengan asumsi tingkat suku bunga (i) bulan Januari 2019 sebesar 6\% dengan $i$ tidak berubah untuk setiap tahunnya. 
4. Proporsi dari gaji yang dipersiapkan untuk manfaat pensiun $(k)$ sebesar 2,5\% dari gaji selama bekerja.

\section{Proses Perhitungan Manfaat Pensiun, Iuran Normal, dan Kewajiban Aktuaria}

1. Manfaat Pensiun

Anggota pertama $(j=1)$ adalah seorang perempuan bernama $\mathrm{S}$ berusia 18 tahun dengan golongan awal II/a dan gaji awal per bulan sebesar Rp 1.540.000,00. Total gaji pada usia $x$ untuk anggota $j\left(s_{x_{j}}\right)$, sedangkan total gaji yang diterima selama bekerja pada usia $x$ tahun $\left(S_{x_{j}}\right)$. Manfaat pensiun yang diterima pada usia $x$ untuk anggota $j\left(B(x)_{j}\right)$ serta selisih manfaat pensiunnya $\left(\Delta B(x)_{j}\right)$ ialah seperti pada Tabel 1.

Tabel 1 Ilustrasi $\left(s_{x_{j}}\right),\left(S_{x_{j}}\right),\left(B(x)_{j}\right)$, dan $\left(\Delta B(x)_{j}\right)$ untuk anggota kelompok $j=1$

\begin{tabular}{|r|r|r|r|r|r|}
\hline $\begin{array}{c}\text { Usia } \\
(x)\end{array}$ & $\begin{array}{c}\text { Gaji awal } \\
\text { bekerja }\end{array}$ & $\begin{array}{c}\text { Total gaji } \\
\text { pada usia } x \\
\left(s_{x_{j}}\right)\end{array}$ & $\begin{array}{c}\text { Total gaji } \\
\text { yang diterima } \\
\text { selama } \\
\text { bekerja pada } \\
\text { usia } x\left(S_{x_{j}}\right)\end{array}$ & $B(x)$ & $\Delta B(x)_{j}$ \\
\hline 18 & 1.540 .800 & 18.489 .600 & 18.489 .600 & 0 & 462.240 \\
\hline 19 & 1.617 .840 & 19.414 .080 & 37.903 .680 & 462.240 & 485.352 \\
\hline$\cdot$ & $\cdot$ & $\cdot$ & $\cdot$ & $\cdot$ & $\cdot$ \\
. & $\cdot$ & $\cdot$ &. &. &. \\
\hline 25 & 2.168 .060 & 26.016 .724 & 176.559 .203 & 3.763 .562 & 650.418 \\
\hline 26 & 2.276 .463 & 27.317 .560 & 203.876 .764 & 4.413 .980 & 682.939 \\
\hline$\cdot$ & $\cdot$ & $\cdot$ & $\cdot$ & $\cdot$ & $\cdot$ \\
. & $\cdot$ &. &. &. &. \\
\hline 55 & 9.370 .232 & 112.442 .782 & 1.991 .506 .418 & 46.976 .591 & 2.811 .070 \\
\hline 56 & & & $B(y)$ & $\mathbf{4 9 . 7 8 7 . 6 6 0}$ & 0 \\
\hline
\end{tabular}

Pada Tabel 1 proses perhitungan diselesaikan menggunakan software Microsoft Excel. Gaji awal bekerja yaitu $80 \%$ dari gaji pokok sesuai dengan golongan awal. Nilai total gaji pada usia $x$ tahun $\left(s_{x_{1}}\right)$ didapatkan dengan mengalikan gaji pokok pada usia tersebut dengan banyak bulan yaitu 12. Hal ini dikarenakan gaji pokok diterima setiap bulannya selama 12 bulan atau 1 tahun pada usia tersebut, sedangkan untuk memperoleh nilai total gaji pada usia $x+1$ tahun yaitu dengan mengalikan 5\% kenaikan gaji dengan total gaji yang diperoleh pada usia atau tahun sebelumnya. Nilai total gaji yang diterima selama bekerja pada usia $x$ tahun didapatkan dengan menjumlahkan nilai $s_{x_{1}}$ dengan $x$ yang digunakan pada usia awal bekerja $(w)$ sampai usia pensiun $(y)$. Nilai manfaat pensiun yang diterima pada usia $x\left(B(x)_{1}\right)$ diperoleh dari hasil perkalian nilai proporsi dari gaji yang dipersiapkan untuk manfaat pensiun $(k)$ sebesar 2,5\% dengan total gaji yang diterima selama bekerja pada usia $x$ tahun $\left(S_{x_{1}}\right)$. Selisih manfaat pensiun pada usia $x\left(\Delta B(x)_{j}\right)$ diperoleh dari hasil pengurangan nilai manfaat pensiun ditahun yang akan datang dengan manfaat pensiun pada usia $x$.

Selanjutnya manfaat pensiun normal $(y=56)$ untuk anggota $j=1$ dapat dihitung dengan menggunakan rumus manfaat berdasarkan proporsi gaji selama bekerja seperti pada Persamaan (14), yaitu:

$$
\begin{aligned}
B(y)_{j} & =k S_{y-1} \\
B(56)_{1} & =(0,025)\left(S_{56-1}\right) \\
& =(0,025)\left(S_{55}\right) \\
& =(0,025)(1.991 .506 .418) \\
& =49.787 .660
\end{aligned}
$$


Proses perhitungan nilai $s_{x_{j}}, S_{x_{j}}, B(x)_{j}, B(y)_{j}$, dan $\Delta B(x)_{j}$ untuk peserta dana pensiun kedua sampai ketiga puluh satu sama seperti proses perhitungan pada Tabel 1 tergantung dari usia masuk, golongan awal, dan gaji awal masing-masing peserta.

\section{Iuran Normal}

Pada pembahasan sebelumnya telah dihasilkan besar manfaat pensiun yang akan didapatkan oleh setiap peserta. Nilai manfaat yang didapatkan akan berbeda-beda namun dengan selisih yang relatif kecil. Langkah selanjutnya ialah menentukan besarnya iuran normal yang seharusnya dibayarkan oleh setiap peserta. Dengan menggunakan Persamaan (21) maka diperoleh iuran normal untuk masingmasing kejadian sebagai berikut:

\section{Saat $t=0$ sampai $t=20$}

Pada kurun waktu 0-20 tahun kelompok program pensiun $\left(A_{t}\right)$ memiliki 31 anggota kelompok $\left(n_{t}\right)$ dengan nilai suku bunga tahunan ( $i$ ) adalah 6\%, sehingga berdasarkan Persamaan (21) iuran normal yang harus dibayarkan oleh setiap anggota kelompok, yaitu:

$$
\begin{aligned}
N C_{t}^{j}= & \frac{1}{n_{t}} \sum_{j \in A_{t}} B(y)_{j} \ddot{a}_{y}^{(12)} \frac{D_{y_{j}}}{N_{w_{j}}-N_{y_{j}}} \\
= & \frac{1}{31}\left[B(56)_{1} \ddot{a}_{56}^{(12)} \frac{D_{56_{1}}}{N_{18_{1}}-N_{56_{1}}}+B(56)_{2} \ddot{a}_{56}^{(12)} \frac{D_{56_{2}}}{N_{19_{2}}-N_{56_{2}}}+B(56)_{3} \ddot{a}_{56}^{(12)} \frac{D_{56_{3}}}{N_{20_{3}}-N_{56_{3}}}+\cdots+\right. \\
& \left.\quad B(56)_{30} \ddot{a}_{56}^{(12)} \frac{D_{56_{30}}}{N_{35_{30}}-N_{56_{30}}}+B(56)_{31} \ddot{a}_{56}^{(12)} \frac{D_{56_{31}}}{N_{35_{31}}-N_{56_{31}}}\right] \\
= & 3.309 .983
\end{aligned}
$$

Jadi, besarnya iuran normal yang harus dibayarkan oleh setiap anggota $j$ kelompok $A_{t}$ adalah sebesar Rp 3.309.983,00 setiap tahun atau sebesar $\frac{3.309 .983}{12}=$ Rp 275.832,00 setiap bulan.

Proses perhitungan pada saat $t=21$ sampai $t=37$ tahun kelompok program pensiun $\left(A_{t}\right)$ berjalan sama seperti proses perhitungan pada saat $t=0$ sampai $t=20$. Hanya saja semakin lama kurun waktu $t$ berjalan, jumlah peserta semakin sedikit dikarenakan telah mencapai usia pensiun ( $y=56$ tahun) sampai pada kurun lebih dari waktu 37 tahun, anggota kelompok yaitu $j=1$ telah memasuki masa pensiunnya. Akibatnya, $j=1$ berhenti membayar iuran normal dan membuat anggota kelompok $\left(n_{t}\right)$ tersisa 0 orang, sehingga pembayaran iuran normal dari kelompok program pensiun berhenti $\left((N C)_{t_{j}}=\right.$ $0)$.

Gambar 1 menunjukkan nilai iuran normal untuk setiap waktu ialah bersifat konstan namun iuran normal dapat berubah apabila terdapat anggota yang keluar dari kelompok program pensiun. Nilai iuran normal akan mengalami penurunan apabila terdapat anggota kelompok yang memasuki usia pensiun normal $(y=56$ tahun).

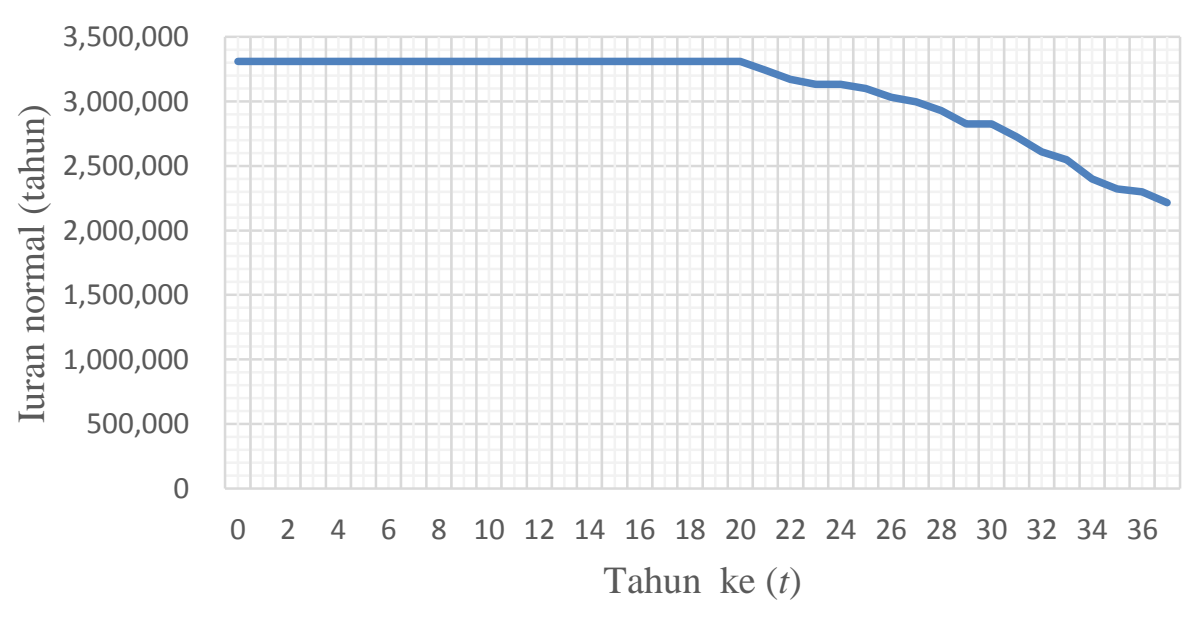


Gambar 1 Perubahan Nilai Iuran Normal dalam Beberapa Tahun

\section{Kewajiban Aktuaria}

Pada pembahasan sebelumnya telah didapatkan nilai manfaat pensiun yang akan diterima oleh setiap peserta dan nilai iuran normal yang akan dibayarkan oleh setiap anggota kelompok pada setiap tahunnya. Nilai manfaat pensiun dan iuran normal tersebut akan mempengaruhi nilai kewajiban yang harus dicadangkan oleh perusahaan dana pensiun setiap tahunnya. Nilai kewajiban aktuaria akan dipengaruhi oleh suatu kasus yaitu terdapat anggota kelompok yang keluar dari sistem pendanaan pensiun disebabkan oleh peserta tersebut telah mencapai usia pensiun normal $(y=56)$. Perhitungan dengan menggunakan nilai-nilai yang didapatkan sebelumnya dan memasukkannya ke dalam Persamaan (22), maka besarnya kewajiban aktuaria pada setiap tahunnya secara berturut-turut adalah:

$$
\begin{aligned}
(A L)_{t+1}= & (A L)_{t}(1+i)-\left(\sum_{j \in T}(P V F B)_{t+1_{j}}-\sum_{j \in A_{t}} q_{x_{j}}(P V F B)_{t+1_{j}}\right)- \\
& \sum_{j \in R}(P V F B)_{t+1_{j}}+\sum_{j \in A_{t+1}} \Delta B(x)_{j} \ddot{a}_{y}^{(12)} \frac{D_{y_{j}}}{D_{x+1_{j}}}- \\
& (N C)_{t+1} \frac{1}{n_{t+1}} \sum_{j \in A_{t+1}} \frac{N_{x+1_{j}}-N_{y_{j}}}{D_{x+1_{j}}}+(1+i)(N C)_{t} \frac{1}{n_{t}} \sum_{j \in A_{t}} \frac{N_{x_{j}}-N_{y_{j}}}{D_{x_{j}}} \\
= & 21.454 .598
\end{aligned}
$$

Jadi, nilai kewajiban aktuaria $(A L)_{t+1}$ yang harus dicadangkan oleh perusahaan dana pensiun saat $t+1$ yaitu sebesar $\operatorname{Rp} 21.454 .598,00$. Pada saat $t \geq 1$ berlaku juga perhitungan serupa dengan $t$ sebelumnya.

Gambar 2 menunjukkan nilai kewajiban aktuaria untuk setiap waktu akan terus meningkat setiap tahunnya meskipun terdapat anggota yang keluar dari kelompok program pensiun, namun pada saat tertentu terdapat penurunan nilai kewajiban aktuaria. Pada saat $t=32$ sampai $t=35$ tahun kelompok program pensiun $\left(A_{t}\right)$ berjalan, nilai kewajiban aktuaria mengalami penurunan ekstrim dikarenakan saat itu terdapat banyak anggota yang keluar secara bersamaan dari kelompok program pensiun. Pada saat $t \geq 36$, nilai kewajiban aktuaria menjadi 0 disebabkan oleh tidak ada anggota kelompok program pensiun yang tersisa.

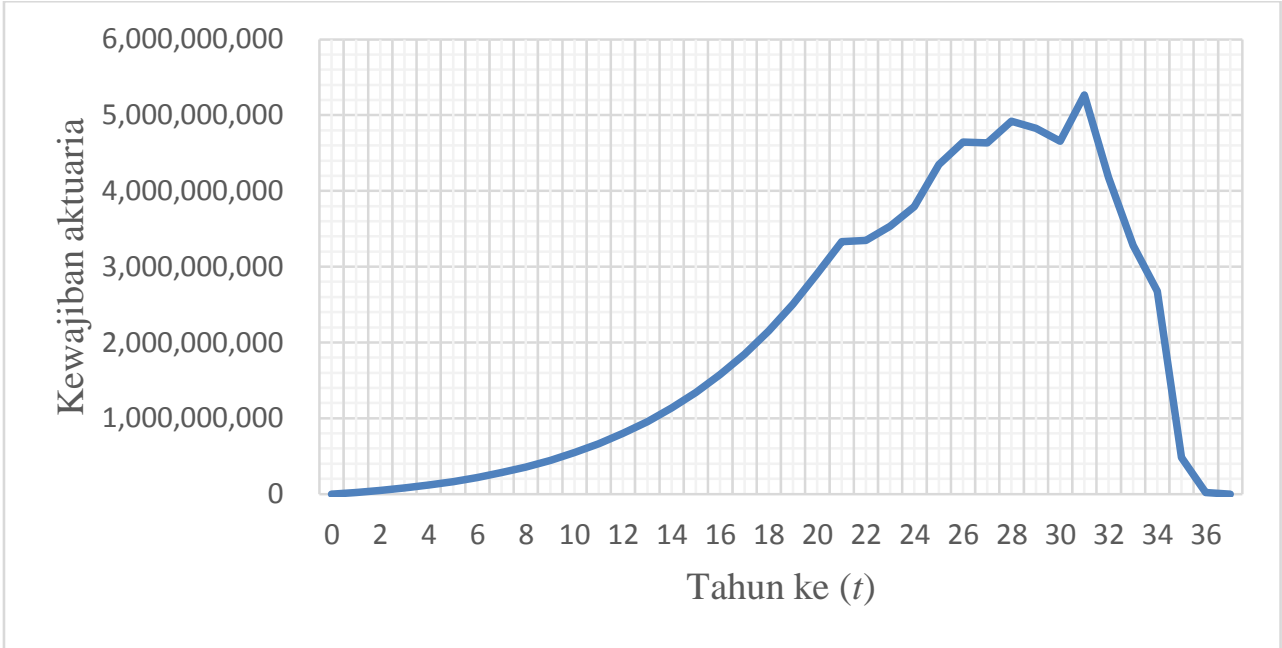

Gambar 2 Perubahan Nilai Kewajiban Aktuaria dalam Beberapa Tahun

\section{KESIMPULAN}

1. Berdasarkan hasil perhitungan, didapatkan bahwa nilai iuran normal yang dihitung dengan menggunakan metode Frozen Initial Liability (FIL) untuk setiap waktu ialah bersifat konstan namun iuran normal dapat berubah apabila terdapat anggota yang keluar dari kelompok program pensiun. 
2. Nilai iuran normal akan mengalami penurunan apabila terdapat anggota kelompok yang memasuki usia pensiun normal ( $y=56$ tahun). Nilai kewajiban aktuaria akan terus meningkat setiap tahunnya meskipun terdapat anggota yang keluar dari kelompok program pensiun, namun pada saat tertentu terdapat penurunan nilai kewajiban aktuaria.

\section{DAFTAR PUSTAKA}

[1]. Futami, T. Matematika Asuransi Jiwa Bagian II. Herliyanto G, penerjemah. Tokyo: Oriental Life Insurance Cultural Development Center. Terjemahan dari: Seimei Hoken Sugaku, Gekan (“92 Revision). 1994.

[2]. Winklevoss, Howard E. Pensiun Mathematics with Numerical Illustration. Philadelphia: University of Pennsylvania. 1993.

[3]. Gajek, L and Krzysztof M. Ostaszewski. Financial Risk Management for Pensiun Plans. Amsterdam: Elsevier. 2004.

[4]. Dickson, David C. M. dkk. Actuarial Mathematics for Life Contingent Risks. New York: Cambridge University Press. 2009.

[5]. Kellison, Stephen G. The Theory of Interest ( $\left.2^{\text {nd }} e d\right)$. McGraw-Hill: USA. 1991.

[6]. Anderson, Arthur W. Pensiun Mathematics for Actuaries Third Edition. Winsted: ACTEX Publications. 2006.

$\begin{array}{ll}\text { ZUL ALFIKRI } & \begin{array}{l}\text { : Jurusan Matematika FMIPA UNTAN, Pontianak } \\ \text { zalfikri45@ gmail.com }\end{array} \\ \text { NEVA SATYAHADEWI } & \begin{array}{l}\text { : Jurusan Matematika FMIPA UNTAN, Pontianak } \\ \text { neva.satya@ @math.untan.ac.id }\end{array} \\ \text { HENDRA PERDANA } & \begin{array}{l}\text { : Jurusan Matematika FMIPA UNTAN, Pontianak } \\ \text { hendra.perdana@math.untan.ac.id }\end{array}\end{array}$

